\title{
ORIGIN AND DISPERSAL OF FLOWERING PLANTS
}

\begin{abstract}
A TOTAL of no less than thirty-nine papers presented at the Montreal Ninth International Botanical Congress during August 19-29 dealt directly or indirectly with the origin and dispersal of flowering plants, providing a modern commentary on these two long-standing fundamental questions.

A review of the evidence for a pre-Cretaceous origin was given in two invited papers before a joint symposium of the palæobotany and morphology and anatomy sections. In the first of these A. J. Eames, discussing morphological testimony for a Palæozoic origin, maintained that studies in the Ranales showed that the primitive flower was bisexual and beetle-pollinated, that unisexuality and dicecism accompanied by insect pollination, then anemophily and the elaboration of simple sporophylls, were major advances which must have required long periods of time. These steps had already been taken before the Lower Cretaceous. Eames suggested that the search for ancestral angiospermous stock might again be directed towards the late Palæozoic ferns, even possibly the homosporous ones. Besides the evidence from comparative anatomy, there was direct evidence in the form of pollen, wood and leaf impressions from the Triassic and Jurassic.

L. Van der Pijl, opening the Darwin Centennial Symposium, considered that the angiosperm flower must have differentiated in contact with beetles, already present in the Permian, whereas insects are not common until the Cretaceous. Persisting traces of beetle pollination, he pointed out, are found in extant groups. V. Grant, in an account of the diversity of pollination systems in the Polemoniaceae, appeared largely to concur with Van der Pijl's view of the primitive flower. In different papers, A. S. Foster described how certain herbaceous ranalean forms might represent an early angiospermous type with dichotomous venation; W. N. Stewart proposed that Conrad's monophyletic classification of vascular plants be revived, despite the recent trend towards a polyphyletic one.

The difficulties inherent in the discovery of palæo-
\end{abstract} botanical evidence of angiospermous origins were illustrated by $\mathrm{N}$. H. Hughes, who demonstrated Jurassic probably gymnospermous pollen, and by W. G. Chaloner, who described how carboniferous plants with spores which could be found occurring commonly could nevertheless be poorly represented as macro-fossils. On the other hand, in a paper on Palæozoic marine sequences from New York and Australia, W. R. Evitt further documented the antiquity of vascular plant stocks.

In the second invited paper of the first symposium D. I. Axelrod dealt primarily with a third line of evidence, namely, modern distribution patterns. $\mathrm{H}_{\theta}$ illustrated with tables the preponderance of families entirely or largely tropical or with a large tropical section. Basic distribution patterns which emerged were tropical ; tropical and extra-tropical, boreal or austral ; dry and temperate derived. Such evidence, Axelrod considered, favours the supposed existence of angiosperms in the later Palæozoic in upland tropical regions where they underwent quantum evolution.

Many biosystematic, palynological and palæological papers dealt to a greater or lesser extent with flower- ing plant distribution. E. Hulten, opening a sym. posium on alpigenous and arctogenous plants with specific illustrations of various types of circumpolar evolution, pointed out that increasing knowledge of this kind provided further material for Quaternary phytogeography. W. A. Weber directed attention to the southern survival of many arctic and sub-arctic species, more especially in the Colorado Rocky Mountains. E. Dahl, considering amphi-Atlantic arcticalpine plants, discussed evidence for their migration across a Pliocene or Pleistocene land-bridge. Dahl suggested that the West Arctic Scandinavian species survived the last ice-age in coastal refugia rather than in Central Europe. A. Tolmatchev, in an abstract, stated that the Arctic flora was first formed in the Pliocene-Pleistocene, from indigenous elements in the treeless areas on mountain summits and slopes and similar open habitats. T. W. Böeher held that most arctic or montane species groups are probably of Tertiary origin, but that considerable speciation occurred within these groups in the Quaternary, supported by geographical or genetical barriers. J. A. Calder, discussing post-Pleistocene distributions in British Columbia, suggested that extensive refugia had existed in Alaska, the Yukon, also in the mountains of west Mackenzie and the Queen Charlotte Isles during the period of maximum glaciation.

On modern montane distributions, K. O. Hedberg described the Afro-alpine flora as a complex derived from Mediterranean, Himalayan, South African and Temperate, besides Tropical African floras, and which had probably existed since the Miocene. J. K. Morton found a higher incidence of polyploidy in the Cameroons mountain flora than in lowland Ghana; I. Manton, in a presentation otherwise restricted to ferns, referred to this Cameroons flora as an "island" one, comparable with that of Ceylon in respect of the occurrence of polyploidy. C. Favarger described how the incidence of polyploidy in Switzerland in certain alpine groups coincided with a floristic subdivision. G. S. Puri considered that during the Pleistocene glaciation the Himalayas wore invaded by conifers, so that pure conifers or oak-conifer seral stages may now be found there alongside oak climaxes. In an abstract B. Pawlowski stated that there could have beən many survivors of an endemic Tertiary flora on the east and some on the west of the Carpathians. P. Gorchakovsky similarly described how, apart from endemies, the Ural flora was composed of relies from pre-Glacial broad-leaved forests and glacial ones, from mountain steppe of Asiatic origin and from Pleistocene high mountain relics of Asiatic and of Siberian origin.

Dealing with restricted aspacts of modern temperate floras, A. J. Sharp thought that much of the flora of the newer coastal plains of Tennessee and the glaciated terrain to the north were segregates of a more ancient flora of the Southern Appalachian highlands. L. Laasimer divided the flora of Estonia into East Baltic, related to eastern Europe and West Baltic to Central Europe, respectively. A. A. Beotle discussed how, in the southern part of central Wyoming, differences in grass distribution were due to differences in the age and origin of the various species. In the Cretaceous, the Tethys Sea, by dividing the Old 
World climates, established contrasts between the predominantly tropical panicoid and the predominantly temperate festucoid grass types. Describing the phytogeography of Chinese species of Fraxinus, Shiu-Ying Hu stated that one species of a primitive group extended to Sumatra, two species from west and central China have close affinities with north American species, one from north China and one from Yunnan are close to European species.

For tropical floras, A. Liogier held that Cuba, although tropical, drew most of its species from subtropical and temperate North America. The present Cuban distributions suggest that the bulk of the flora came chiefly from South America through Central America during the Mesozoic and Cainozoic, when Cuba and Jamaica were united with Honduras. L. B. Smith described how the flora of south Brazil had its greatest source in central Brazil, there being continuous linkages with the Amazon, Andes and Argentine, discontinuous ones with the Amazon, North America, the Andes and Africa. The mountainous and the low-lying floras of tropical America were considered by F. Miranda to have had a greater diffusion in past Tertiary periods. These floras were partially dominated later in tropical zones by a more macrothermic flora, and almost eliminated in North America by a more microthermic one.

Papers were provided by K. A. Chowdhury, E. Dorf, W. L. Fry, J. Gray, T. Jimbo and K. Rasky, describing angiosperms in various Tertiary floras of India, Wyoming, Canada, Oregon, Japan and Hungary respectively. C. A. Arnold and J. S. Lowther and J. F. Grayson and R. L. Pierce illustrated the low representation of angiosperms in two American Cretaceous floras. L. A. Kuprianova described how palynological studies suggested that Liquidambar already occurred in the Upper Cretaceous, that it is not a typical representative of the Arcto-Tertiary flora, and indicated ancient floral relationships between the Mediterranean, Central America and Eastern Asia. In a paper to the Taxonomy Section, J. Ewan reminded botanists that zoogeographical data may prove illuminating in the interpretation of existing floristic patterns, eiting examples including that of the wood rat which persists together with the relict Sierra Madrean flora on outlying Rocky Mountain summits.

\section{A. S. BOUGHEY}

\section{THE NATIONAL HEALTH SERVICE IN BRITAIN}

$\mathrm{T}$ HE Acton Society Trust has produced a valuable survey of the National Health Service in Britain prepared by Sir George Schuster*. Part of the report is a discussion of the general problems of leadership in a State service; this has been dealt with elsewhere (see Nature, October 10, p. 1087).

Sir George then returns to the National Health Service itself. He starts with two personal observations. With keen appreciation of the achievements of the National Health Service in Britain in these first ten year's, and the belief that too little was far better than too much interference from the central authority, he believes that the time has come for a general overhaul and tuning-up of the administrative machine, for an interpretation of the lessons to be learned from the practical experience of these first ten years, and for a new effort, in the light of this practical experience, to understand what is required to ensure that the National Hospital Service can meet the true needs, individual and social, of the people of Britain in these times. Secondly, writing as one desperately anxious to see the best use made of this fine Service, he emphasizes the immense burden of current routine work now falling upon the senior staff of the Ministry. This has left them with far too little time to attend to many of the things he suggests need to be done.

This matter of overburdening the senior officials is not confined to the Health Service, and although its seriousness has often been admitted since the War, there is little indication that much has been done to relieve the situation. All these, however, are matters that could bear closely on the work of other sections of the public service, where the administration of highly technical matters and the control of technical and professional staffs are involved. It is to such major issues that Parliament might well have been

* Creative Leadership in a State Service: a General Survey. (Hospitals and the State. Hospital Organization and Administration under the National Health Service, Sixth and Final Research Paper. Pp. iii +80 . (London: Acton Society Trust, 1959.) $4 s$. expected to give its attention; but apart from Sir Keith Joseph's reference to the need for a research or planning staff in the Ministry, they were unnoticed in the House of Commons debate on the National Health Service on July 15.

It is the quality of Sir George Schuster's thought and the character of his approach rather than his particular proposals that are of most general interest. While he has always conceived of the hospital service as a great fighting service, in which the heads of hospital boards should be entitled to expect from the Ministry something like the leadership and direction which army commanders would get from their commander-in-chief and his general headquarters, he stresses the paramount importance of keeping the hospital service human. Inadequate leadership, inefficient management, muddled organization can destroy all possibility of the workers in the service getting satisfaction from their work in a manner that keeps alive their enthusiasm and fulfils a sense of vocation. This, however, is an essential element in providing what the patients themselves require above all-efficient curative treatment-and Sir George is well aware that good organization is only a means to an end and he reminds us that in the widest sense the welfare of the patients means taking into account their comfort, peace of mind and all the psychological and social implications of stays in hospital.

Sir George does not devote space to the consideration of these issues. $\mathrm{He}$ is content to note them among the great needs and opportunities in this service which call for a combination of hard-headed administrative efficiency, highly developed working skills, single-hearted pursuit of scientific knowledge and human kindness. There are other fields in which the demands are no less, and even if in them it might bo too much to assert that without human kindness the true purpose and value of the work must fail, without it full success or true efficiency are hard to achieve. 